\title{
太陽エネルギー利用のための分光日射量の測定と整理*
}

(第 1 報, Bird のモデルに基つく分光日射特性の比較)

\author{
馬場弘*1, 金 山公夫*1 \\ 遠 藤 登*1, 金 澤 浩 志*2

\section{Measurement of Spectral Insolations and Processing the Data for Solar Energy Utilization} \\ (1st Report, Comparison of Spectral Insolation Based on “Bird's Model”)
}

\author{
Hiromu BABA, Kimio KANAYAMA, \\ Noboru ENDOH and Hiroshi KANAZAWA
}

\begin{abstract}
Since August 1994, spectral measurements of the global and direct insolations have been carried out by the authors. According to the intensity of the insolation, the results measured were arranged by classifing into rank of $100 \mathrm{~W} / \mathrm{m}^{2}$ each; then. comparing the insolation with Bird's model, the factors of solar altitude, turbidity of atmosphere, precipitable water and albedo of the earth were investigated. Consequently, on a clear day on which cloud amount was less than six, the spectra corresponding to the global and direct insolations could be estimated. Different shapes of the spectra in summer and winter depended on the precipitable water; the spectrum of the direct insolation was affected by the turbidity and precipitable water, while the spectrum of global insolation was hardly affected by these factors. In addition, on the basis of Bird's model the direct insolation and transmittance of atmosphere were calculated under several atmospheric conditions, and the influence of solar altitude to the transmittance of atmosphere was clarified.
\end{abstract}

Key Words: Solar Energy, Thermal Radiation, Spectral Insolation, Global and Direct Insolations, Solar Altitude, Turbidity of Atmosphere. Transmittance of Atmosphere, Albedo of Earth, Precipitable Water

\section{1. ま え がき}

太陽エネルギー利用技術は給湯および暖冷房用とし ての熱利用から, 太陽電池, バイオマスおよびソーラ ポンドなど多岐にわたる方法が開発され発展してき た。特に太陽電池の製造方法の発達による低コスト化 は，太陽エネルギーによる電力供給源として注目され， 化不燃料の消費に伴う大気噮境污染を防止する一手段 として期待されるに至った。ところで，太陽エネルギ 一の量としての特性は, 企天时射量および法線面直達 日射量の観測デー夕を基に両者の相関関係や日照時間 によるH射量の推定式等が明らかにされてき た(1) (4). しかし、太陽エネルギーの波長特性について は、いくつかの重要な報告(5) (10) が見られるが, 種々 の天候下で行われる太陽エネルギー利用の立場からは 十分とはいえない状況にある。また分光目射のデー夕 は大気污染の状況を監視して解析するためにも重要で ある。

* 原稿受付 1995 年11月20日1。

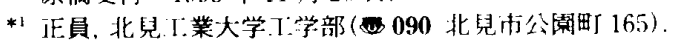

*2 北見 I. 業大学大学院.
著者らはこうした観点に立って，1994 年 8 月から北 見工業大学において分光日射の測定を開始した。ここ では1995年8月までのデータを整理して報告する。

\section{記 号}

C : 散乱修证係数

$h$ :太陽高度。

$I$ :日射エネルギー $W / \mathrm{m}^{2}, \mathrm{~W} /\left(\mathrm{m}^{2} \cdot \mu \mathrm{m}\right)$

$m:$ エアマス

$P$ : 大気压 $\mathrm{hPa}$

$T:$ 透過率

$W:$ 可降水量 $\mathrm{cm}$

$\lambda$ : 波長 $\mu \mathrm{m}$

$\tau_{05}$ : 波長 $0.5 \mu \mathrm{m}$ における混濁度指数

$\rho:$ 反射率(アルベド)

添字

$H:$ 全天成分

$N ：$ 直達成分

$S:$ 散乱成分

$a$ : エアロゾルによる影響

$g:$ 地表面の影響 


$$
\begin{aligned}
& o: \text { オソンによる影響 } \\
& r: \text { Rayleigh 散乱による影響 } \\
& u: \text { 組成ガスによる影響 } \\
& w: \text { 水蒸気による影響 } \\
& \lambda: \text { 波長特性 }
\end{aligned}
$$

\section{Bird のモテルによる分光日射特性}

分光日射特性を与えるモデル式は，大気圈外の分光 日射測定および高層気象観測などの技術の進步に伴っ て進展してきたが，現在のところ種々の大気条件に対 応できるものとして，Bird(9) のモデル式が最も具体的 で扱いやすいと考えられる。一般に大気圏外に到達し た太陽エネルギーは，大気層を通過する間に大気によ る吸収と散乱を受けて減衰し，地上に到達した日射エ ネルギーの波長分布は非常に複雑な形を示すことはよ く知られている。こうした分光日射のうち法線面值達 日射成分のスペクトル分布は式(1)によって示され る.

$I_{N \lambda}=I_{o \lambda} T_{r \lambda} T_{a \lambda} T_{o \lambda} T_{w \lambda} T_{u \lambda}$

ここで,

$I_{O \lambda}$ : 大気圈外分光日射量

$T_{r \lambda}$ : Rayleigh 散乱による透過率

$T_{a^{\lambda}}:$ エアロゾルによる透過率

$T_{o \dot{⿰}}$ :オゾン廨による透過率

$T_{w \lambda}$ : 水蒸気による透過率

$T_{u \lambda}$ : 気体成分による透過率

である。

透過率に影響を与える大気経路(エアマス) $m$ は式 (1)で与えられる.

$$
m=\left[\sin h+0.15(h+3.885)^{-1.253}\right]^{-1} P / 1013
$$

$こ こ て ゙$,

$$
\begin{aligned}
& h: \text { 太陽高度 } \\
& P: \text { 大気圧 }
\end{aligned}
$$

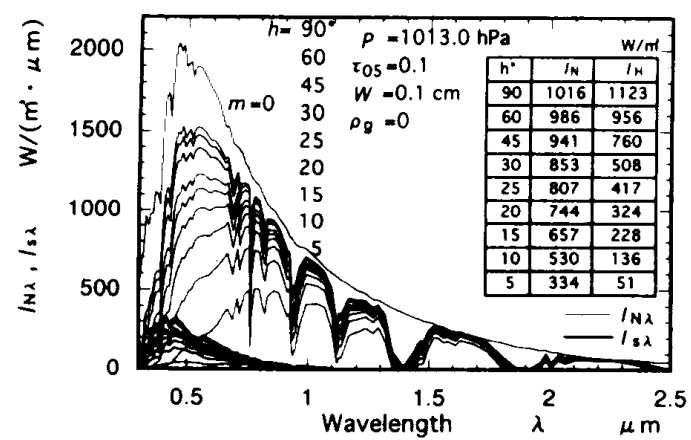

Fig. 1 Direct and diffuse components of the spectral insolation calculated by Bird's model $\left(\rho_{g}=0.0\right)$
である。

地表面における散乱日射成分のスペクトル分布は式 ( 3 ) で求められる.

$$
I_{s \lambda}=\left(I_{r \lambda}+I_{a \lambda}\right) C_{\lambda}+I_{g \lambda}
$$

ここで

$$
\begin{aligned}
& I_{s \lambda}: \text { 分光散乱日射量 } \\
& I_{r \lambda}: \text { 地表面における Rayleigh 散乱成分 } \\
& I_{a \lambda}: \text { エアロソルルによる散乱成分 } \\
& I_{g \lambda}: \text { 地表面と大気との間の反射成分 }
\end{aligned}
$$

である. $C_{\lambda}$ は散乱成分の修正係数で波長 0.5 における 大気の混濁度 $\tau_{05}$ をパラメータとして $0.1,0.27,0.37$ お よび 0.5104 種類について与えられている.

全天日射のスペクトル分布は $I_{H \lambda}$ は式 $(4)$ で求めら れる。

$$
I_{H \lambda}=I_{N \lambda} \sin h+I_{s \lambda}
$$

全天日射量, 放線面直達日射量および散乱日射量は それぞれ式(4)，(1)および式(3)を波長 $0 \mu \mathrm{m}$ から めまで積分することによって求められる。

図1は式（1）および式（3)によって求めた法線面直 達日射量と散乱日射量の波長分布を示す，大気の状態 は $1 \mathrm{~atm}$ で大気の透明度を表す指標として用いられ る波長 $0.5 \mu \mathrm{m}$ における大気の混罣度 $\tau_{05}$ を 0.1 , 大気 中の水蒸気量を示す可降水量 $W$ を $0.1 \mathrm{~cm}$, 地表面の 反射率 $\rho_{g}$ を 0.0 としたものである.エアマス $m=0$ は大気圈外の日射スペクトルであり，以下太陽高度 $h$ をパラメータとして $90^{\circ}(m=1), 60,45, \cdots 5^{\circ}$ について 示す，紐い実線は法線面直達成分を，太い実線は散乱 成分を示す，Birdのモデルでは，エアロソルによる散 乱と吸収の影響を $\tau_{05}$ をパラメータとして波長带を $0.3 \sim 0.5 \mu \mathrm{m}$ と $0.5 \sim 4.0 \mu \mathrm{m}$ の二つに分割して評価 している.これに Rayleigh 散乱と大気中の水蒸気お よび $\mathrm{O}_{3}, \mathrm{CO}_{2}$ などの混合がスによる吸収の影響が加 わって分光茾射スペクトルが形成される。太陽高度に

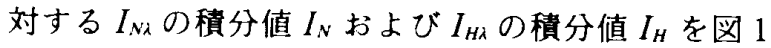

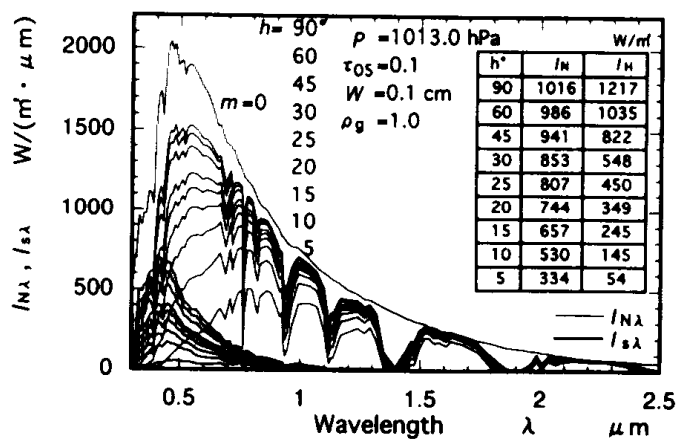

Fig. 2 Direct and diffuse components of the spectral insolation calculated by Bird's model $\left(\rho_{g}=1.0\right)$ 


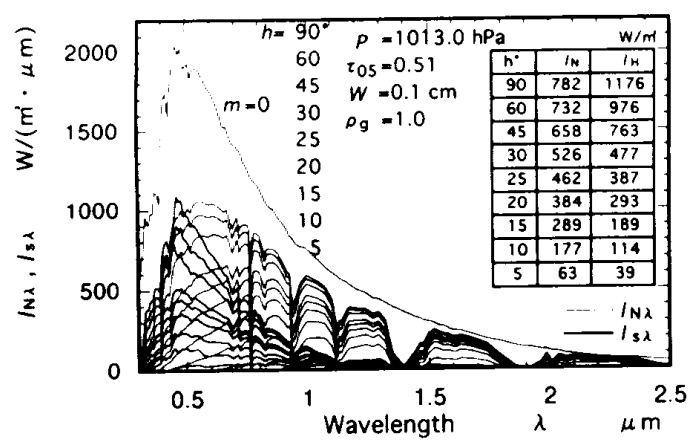

Fig. 3 Direct and diffuse components of the spectral insolation calculated by Bird's model $\left(\tau_{05}=0.51\right)$

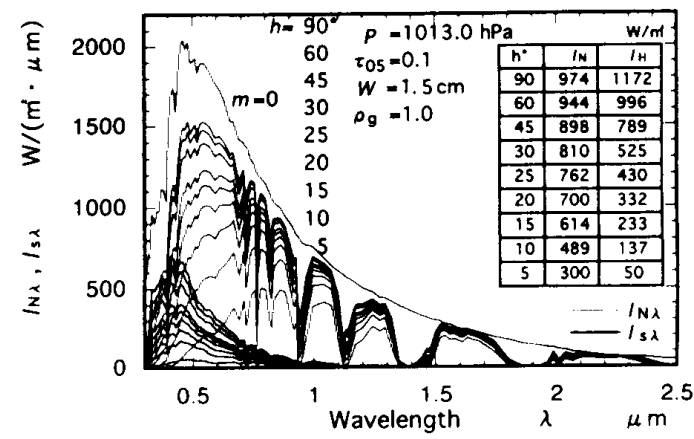

Fig. 4 Direct and diffuse components of the spectral insolation calculated by Bird's model ( $W=1.5$ $\mathrm{cm}$ )

中の表に示す。図1で与えた計算条件は，大気が最も 透明であり，さらに地面の反射率 $\rho_{g}$ を0.0としたた めに，散乱成分のスペクトルは小さく，エネルギーが 分布する波長域も $0.3 \sim 1.0 \mu \mathrm{m}$ で, $0.6 \mu \mathrm{m}$ 以上の波 長域にある吸収帯も非常に小さい。そして, 法線面直 達成分はエネルギー密度が最大となるピーク波長が太 陽高度の低下に伴って長波長側にずれるのに対し, 散 乱成分はピーク波長が約 $0.480 \mu \mathrm{m}$ のほほ一定值を示 す.

図 2 は日射スペクトルに与える地面の反射率の影響 を検討するために，図 1 と同じ大気条件で地面の反射 率のみを 1.0 としたものを示す。結果として, 直達成 分 $I_{N}$ は図 1 と同じであるが散乱成分は大気と地面と の多重散乱効果により増加し，その影響は全天日射量 にして 6〜8\%増大することがわかる。

図 3 は大気の混濁度の影響を見るために， $\tau_{05}=0.51$ ， 地面の反射率を 1.0 としたものを示す。この場合法線 面直達日射成分 $I_{N}$ は図 20 場合と比較してピーク波 長で $m=1$ に対して約 $65 \%$ に隇少し, 全波長エネルギ 一 INに対しては $h$ の減少に伴って 23〜 68\%も減少す る.しかし太い実線で示される散乱成分が極めて大き くなっている.この結果 $I_{H}$ の値は図 2 の場合と比較

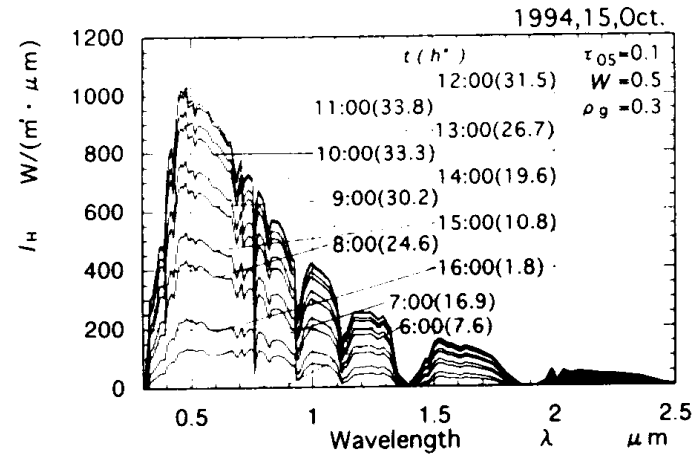

Fig. 5 Relationships between altitude of sun and spectra of the global insolation calculated by Bird's model

して 4〜25\%隇少するにすぎない。このことから地面 が雪に覆われる冬期間において散乱成分の重要性が増 加することがわかる。

図 4 は大気中に含まれる水蒸気の影響を示すために 図 2 の条件から可降水量 $W$ を $1.50 \mathrm{~cm}$ に増加したも のである、Wは地域の気象状態によって異なるがグロ 一バルな視点では低緯度地域では大きく, 高緯度地域 では小さい。そして中緯度地域の緯度 $45^{\circ}$ 付近では $W$ $=0.9 \mathrm{~cm}$ (冬期), $2.9 \mathrm{~cm}$ (夏期) と報告(8)されている. $W$ の増加は水の吸収帯である波長 $0.593,0.823 \mu \mathrm{m}$ お び $0.940 \mu \mathrm{m}$ 付近において分光エネルギーが小さくな ることである。しかし全波長にわたる積分値に与える 影響は，図 2 に示される $I_{N}$ およ゙ $I_{H}$ と比較して $m=$ 1 において約 $4 \%$ 小さくなることがわかる.

図 5 は式(4)上り求めた 10 月 15 日の全天日射スぺ クトルを示す。大気条件は図 1 の場合と同じで $\rho_{g}=$ 0.3 とした。 パラメータの太陽高度 $h$ は10月15日の

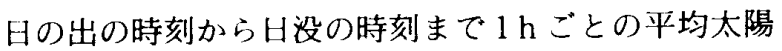
高度で, 晴天日の分光日射スペクトルの1日の推移を 示す。

\section{3. 測 定 方 法}

測定に用いた分光計は回折格子形多目的分光放射計 (MSR-7000/00，オプトリサーチ社)で, 測定波長範囲 は $0.280 \sim 2.500 \mu \mathrm{m}$, 分解能 $0.005 \mu \mathrm{m} て$, 測定值は $0.001 \mu \mathrm{m}$ ごとにフロッピーディスクに収録される.検 出器は波長 $0.280 \sim 0.800 \mu \mathrm{m}$ までは光電子增倍管, $0.800 \sim 1.100 \mu \mathrm{m}$ まではシリコンフォトダイオード (Si)，1.100〜2.500 $\mu \mathrm{m}$ までは硫化鉛(PbS)が用いられ ている.光学系, 波長コントロール, 検出器の切換え等 はパーソナルコンピュータによって自動的に行われ る.

図 6 は分光計のシステムブロック線図を示す。 図 7 は全天日射および直達日射の分光測定の方法を 


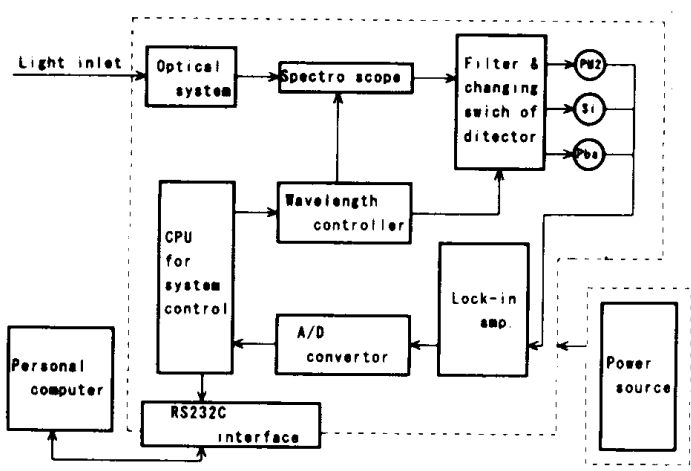

Fig. 6 Blockdaigram of spectroradiometer for measurement of spectral insolation

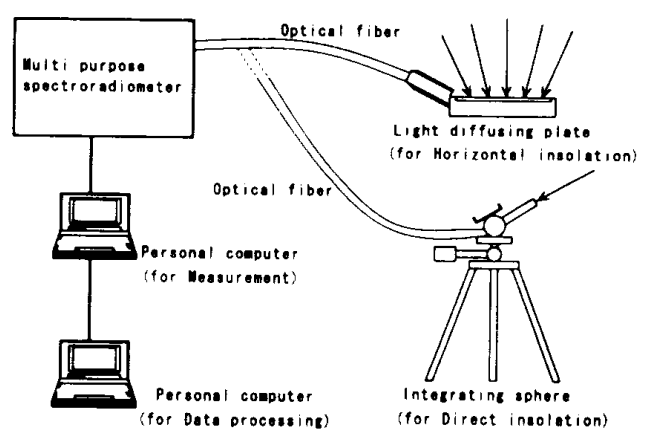

Fig. 7 Measurement method of the spectral insolation

示す. 全天日射の分光測定は分光計の光導入用の光> アイバの先端に反射型㹡散板ュニットを取付けて水平 に固定して行う。一方法線面直達月射の測定はフード 付き積分球に光ファイバを取付け，三脚_上に固定した 積分球のフードを太陽に直面させて行う。1回の測定 には約 $2 \min$ を要するため,この間雲によって日射強 度が急変することがないように注意が肝要である。

測定は日の出の時刻から日没まで，每正時を見当に $1 \mathrm{~h}$ ごとに行い，必要に忍じて $30,20 \mathrm{~min}$ 間隔でも行 った。同時に測定した項目は大候, 雲量, 全天日射最, 気温，湿度，風速㧍よび夫空の写真撮影を行った。さら に自然エネルギー実験室で測定している全天月射量お よび法線面直達谢量のデータを参照した。

データ処理は光磁気ディスクを装備した 2 台のパー ソナルコンピュータで行っている.

\section{4. 測定結果および考察}

図8 は1994 年 10 月 28 日0分光日射測定值の時刻 変化を示す. 図 $8(\mathrm{a})$ は全天时射の分光値を，8(b) は法線面直達日射の分光値を，時刻をパラメータとし て 9 時から 16 時まで毎正時の值を示す。この日は晴天 日で気温 $13 \sim 16^{\circ} \mathrm{C}$, 湿度 $45 \sim 55 \%$, 風速 $0 \sim 1.0 \mathrm{~m} / \mathrm{s}$,

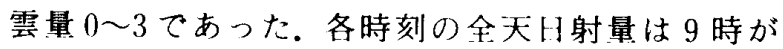

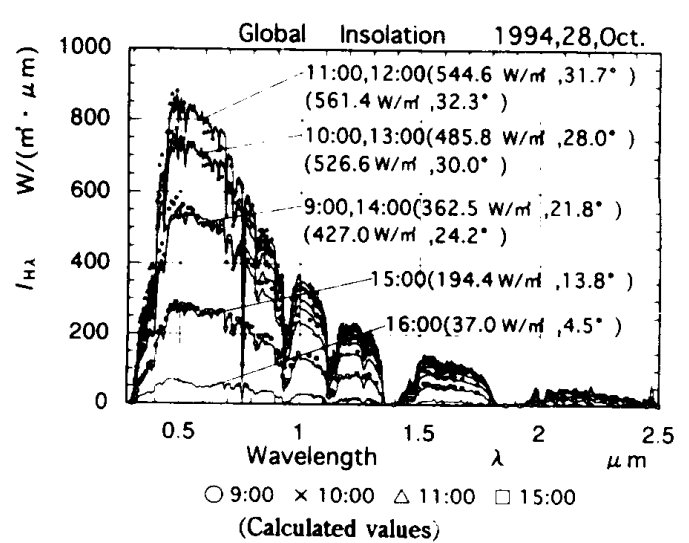

(a) Hourly change of spectra of the global insolation mea. sured and comparison between the measurements and calculations

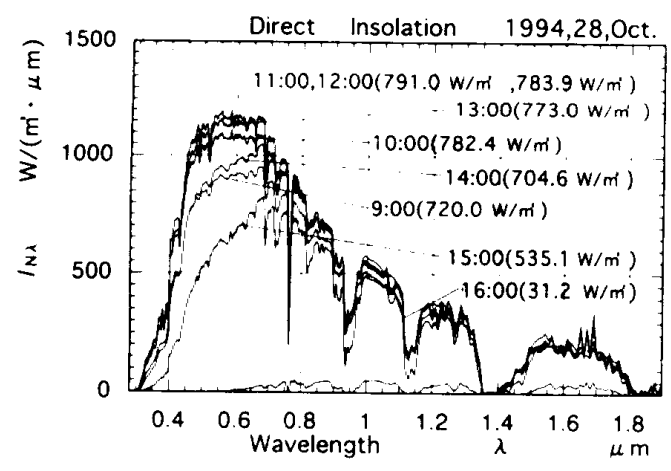

(b) Iourly change of spectra of the direct insolation

Fig. 8

$427.0 \mathrm{~W} / \mathrm{m}^{2}$, 以後 $526.6(10: 00), 561.4(11: 00)$, $544.6(12: 00), 485.8(13: 00), 362.5(14: 00)$, 194.4(15:00), そして 16 時の值が $37.0 \mathrm{~W} / \mathrm{m}^{2}$ であり, これに対応する各時刻の太陽高度 $h$ は $24.2^{\circ}(9: 00)$, $30.0,32.3,31.7,28.0,21.8,13.8^{\circ}$ および $4.5^{\circ}(16: 00) て ゙$ あった。

このように晴天日の分光日射量の時刻変化は太陽高 度の時刻変化と対応する。図 8 (a)の○、×、么お上び 口印はBirdのモデルょり計算した測定日の 9，10， 11 時および 15 時の全天日射の分光スペクトルを表し， 測定值とその傾向および値がよく一致する。そしてエ ネルギーのピーク值を示す波長がおよそ $0.48 \mu \mathrm{m}$ の一 定值を示すことがわかる。

図 8(b)の法線面直達日射のスペクトルは，その積 分值である法線面直達日射量は 9 時の $720.0 \mathrm{~W} / \mathrm{m}^{2}$ か ら 15 時の $535.1 \mathrm{~W} / \mathrm{m}^{2}$ まで変化しており,全天日射 量の場合よりも時刻変動の幅は小さい。これは法線面 直達日射が太陽高度の変化に伴うエアマスの変化の影 響のみを受けることによるもので，その影響は波長 0.3 0.7 $\mu \mathrm{m}$ までのエネルギー密度の大きい波長域に 現れる。そして最大のエネルギー密度を与えるピーク 波長も 11 時および 12 時の約 $0.5 \mu \mathrm{m}$ から 15 時の 0.65 
$\mu \mathrm{m}$ まで時刻とともに変化する。この傾向は図 $1 \sim 4$ に示すBirdのモデルと一致している. 16 時のデー夕 は日没直前のデータで大気の低い位置にかすみのよう なものが濃くたなびいており，その影響を受けたもの と思われる。

ところで分光日射特性は, Birdのモデルに示され るように，太陽高度と大気混鲨度および可降水量など の影響を受ける。太陽エネルギー利用の立場から、こ れらのパラメータを推定することはかなり厄介なこと である。一方, 全天日射量はこれらのパラメータの 種々の值のもとで得られた積分値であり，これをパラ メータとして使用することが最も扱いやすい。図 1 〜 4 に示すように $\tau_{05}$ を $0.1 \sim 0.51, W=0.1 \sim 4.0 \mathrm{~cm}$, $h$ を $90^{\circ}$ まで変化させて全天日射量を求めて検討 した結果, 全天日射量を $100 \mathrm{~W} / \mathrm{m}^{2}$ でランク分けして 示す方法が有効と考えられる。值達田射についても同 様なことがいえる。

図 9 は 1995 年 1 月の晴天時の測定された日射スペク トルを全天日射量および法線面直達日射量で $100 \mathrm{~W} /$ $\mathrm{m}^{2}$ ごとにランク分けして示す。ここで晴天時とは測定 時に法線面直達成分を観測できることを示す、気象条 件仕気温 $-10 \sim 10^{\circ} \mathrm{C}$, 湿度 $20 \%$ 以下, 風速 $0 \sim 2 \mathrm{~m} / \mathrm{s}$, 雲量 0 〜 5 であった。図 9 (a) に示す全天日射量は 100

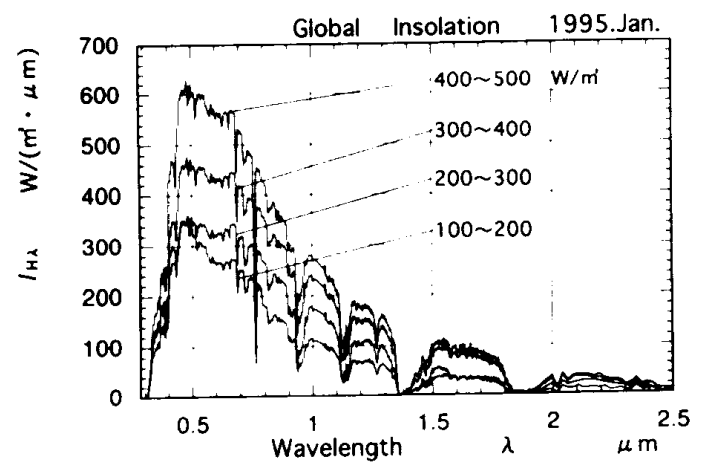

(a) Spectral global insolation classified into every rank in January

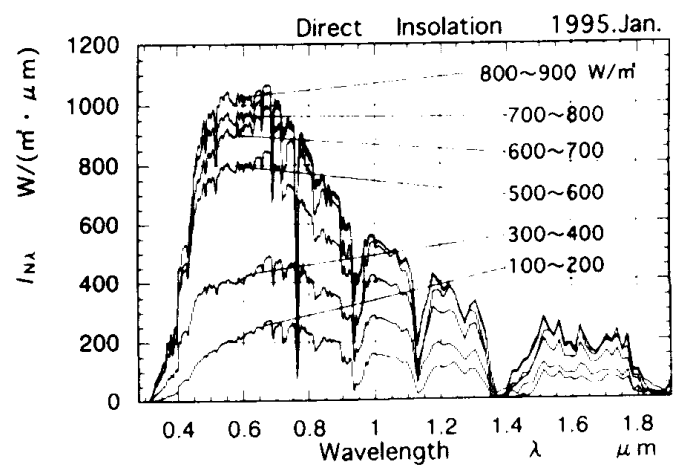

(b) Spectral direct insolation classified into every rank in January

Fig. 9
〜 $200 \mathrm{~W} / \mathrm{m}^{2}$ から 400〜 $500 \mathrm{~W} / \mathrm{m}^{2}$ の 4 ランクしかな い. 各ランクともピーク波長は $0.48 \mu \mathrm{m}$ で一致してい るが、全波長にわたる各ランク間の関係は，波長 0.8 〜 $1.4 \mu \mathrm{m}$ の間でほほ各ランクに比例した対応が見ら れる. 波長 $0.5 \mu \mathrm{m}$ 以下と $1.4 \mu \mathrm{m}$ 以上の範囲ではこう したき机いな関係は見られない。これは、この季節の 日射量が小さく，したがって分光エネルギーが小さい 両端の波長域で誤差が大きく現れたものと思われる。 $300 \sim 400 \mathrm{~W} / \mathrm{m}^{2}$ 以下のランクで見られる $0.5 \sim 0.7 \mu \mathrm{m}$ の波長域のたるみ形状は太陽高度が低いときに現れ る。図 9 (b) は法線面直達日射スペクトルを示す. 直 達日射は全天日射と異なり太陽高度の影響を受けない ことからランクは 800 $900 \mathrm{~W} / \mathrm{m}^{2}$ までの 6 ランクが 存在する。 $600 \sim 700 \mathrm{~W} / \mathrm{m}^{2}$ から $800 \sim 900 \mathrm{~W} / \mathrm{m}^{2}$ のラ ンクでは分光スペクトルは赑いに接近している。

図10は，図 9 と同様にランク分けした1995年7月 の測定結果を示す.7月の気象条件は気温 $21 \sim 28^{\circ} \mathrm{C}$, 湿度 $60 \sim 85 \%$, 風速 $0 \sim 2 \mathrm{~m} / \mathrm{s}$, 雲量 0 ○であった。 図8（a)の全天无射量は $0 \sim 100 \mathrm{~W} / \mathrm{m}^{2}$ から 900 $1000 \mathrm{~W} / \mathrm{m}^{2}$ まで10ランク, 図 $10(\mathrm{~b})$ ) 法線面直達

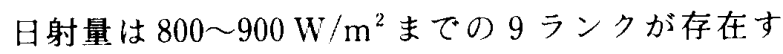
る. 直達日射量の $0 \sim 100 \mathrm{~W} / \mathrm{m}^{2}$ のランクを除いて, 全 天日射スペクトルおよび直達日射スペクトルはいずれ

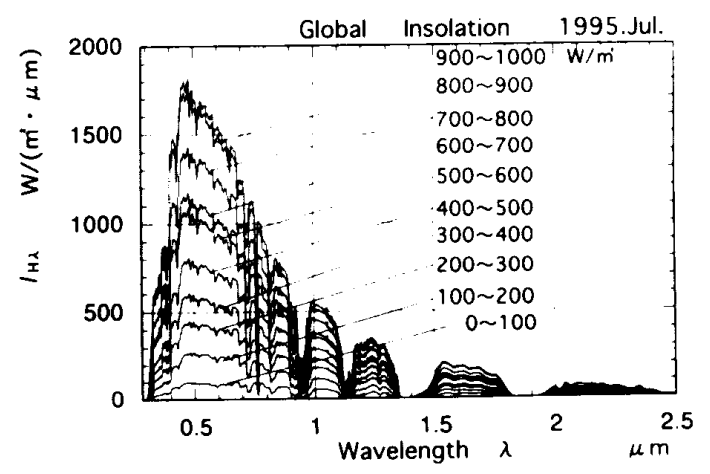

(a) Spectral global insolation classified into every rank in July

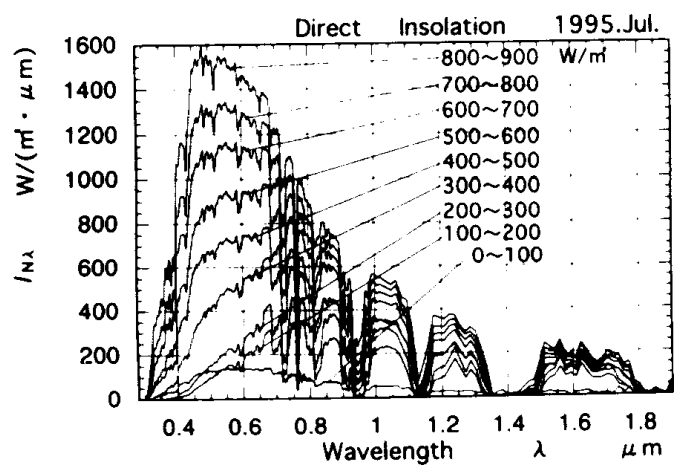

(b) Spectral direat insolation classified into every rank in July

Fig. 10 


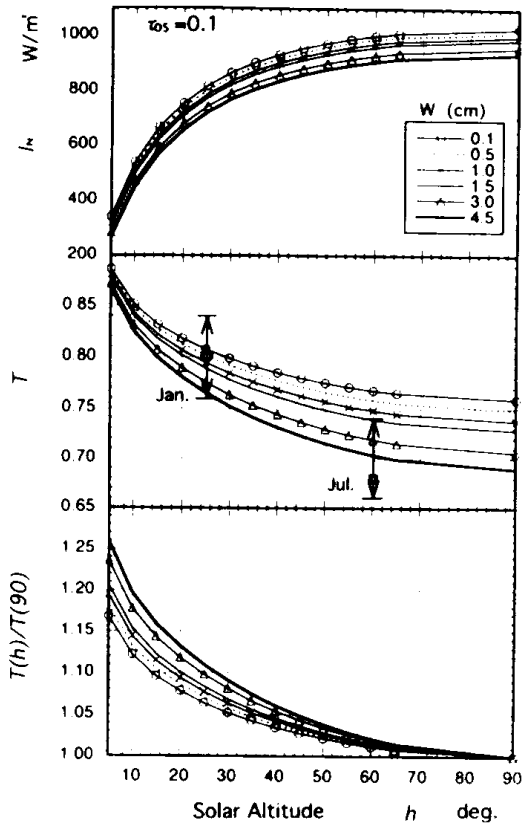

Fig. 11 Relationships between solar altitude and $I_{N}, T, T(h) / T\left(90^{\circ}\right)$

も全波長域にわたって各ランクと対応した整った関係 が見られる.図 10(b) と図 9(b) とを比較して留意す べきことは， 7 月は $h$ が高く $I_{N \lambda}$ の值もピーク値でお よそ $1600 \mathrm{~W} /\left(\mathrm{m}^{2} \cdot \mu \mathrm{m}\right)$ あり，一方1月のそれは 1050 $\mathrm{W} /\left(\mathrm{m}^{2} \cdot \mu \mathrm{m}\right)$ であるにもかかわらず， $I_{N}$ が同じランク に属寸ることである。この現象は主として大気中に含 まれる水分に起因する，夏は絶対湿度が高く空気中の 水分が多いため，図 10（b）０，波長 0.593，0.823，0.940 $\mu \mathrm{m}$ および $1.15 \mu \mathrm{m}$ に見ら机る吸収は図 9 (b) と比較 して大きいことがおかる。

このような点をふまえて Birdのモデルを用いて可 降水量 $W$, 大気㦟罣度 $t_{05}$ 扔上び太陽高度 $h$ に上る $I_{N \lambda}$ と積分値 $I_{N}$ との関係，さらに大気の透過率を求め る.すな⿰ち, 大気の透過率 $T$ は式( 5 ) から求められ る.

$$
\begin{aligned}
T & =\left(I_{N} / I_{0}\right)^{1 / \sin h} \\
& =\left(\int_{0}^{\infty} I_{N \lambda} d \lambda / \int_{0}^{\infty} I_{0 \lambda} d \lambda\right)^{1 / \sin h} .
\end{aligned}
$$

図 11 は $\tau_{05}=0.1, W$ を $0.1,0.5,1.0,1.5,3.0 \mathrm{~cm}$ 扔上 び $4.5 \mathrm{~cm}$ とおいて求めた $ん$ と $I_{N}$ 抢よび $T$ との関係 を示す。北見市の1月に招ける 10 時から 13 時の平均 太陽高度は約 $25^{\circ}, 7$ 月は約 $60^{\circ}, \tau_{05}=0.1$ として $W$ を 冬期 $0.5 \mathrm{~cm}$, 夏期 $3.0 \mathrm{~cm}$ とすると $I_{N}$ の最大值は 1 月 は約 $800 \mathrm{~W} / \mathrm{m}^{2}, 7$ 月は約 $900 \mathrm{~W} / \mathrm{m}^{2}$ となり，図 9 扔 よび図10に示した值はほほ妥当なものと思われる。こ のとき式(5)より $T$ を求めると 1 月は 0.80 .7 月は 0.72 となる。
ところで大気の組成が同じであるならば，Tは $h$ に対して不変であり，式(5)加求められる $T$ は見 掛けの透過率を与えるにすぎない。すなわち 1 月の透 過率 0.80 の真の值は $0.75,7$ 月のそれは 0.71 と考元 られる。このような観点に立って種々の太陽高度で求 めた大気の透過率から真の透過率を求めるために $T(h) / T(90)$ を示す.

$\tau_{05}=0.1$ の場合 $h=45^{\circ} て ゙ T(h) / T(90)$ はすべての $W$ に対して $5 \%$ 以内であるが, $h=20^{\circ}$ では $T$ は 7〜 13\%大きく推定されることがわかる.ちなみに著者 らが行ってきた 17 年間の法線面直達日射量の観測值 から求めた 1 月の大気透過率は $0.76 \sim 0.84$ で平均值は $0.80,7$ 月は $0.66 \sim 0.74$ で平均值は 0.68 であり，真の 平均透過率は 1 月が $0.74,7$ 月は 0.67 と推定される。

\section{5.むすび}

1994 年 8 月から開始した分光H射量の測定結果を 取りまとめBridのモデルと対応させて整理した。こ の結果以下のことが明らかとなった。

（1） $\tau_{05} お$ よび $W$ の增加は $I_{N \lambda}$ および $I_{N}$ を減少 させる。祙 の影響は $0.5 \mu \mathrm{m}$ 付近の波長域を中心に全 波長にわたって大きく作用する。大気中の水蒸気 $W$ が，全波長に与える影響は $\tau_{05}$ よりも小さいが，夏期 と冬期のスペクトルの違いを与える内子として重要で ある。

（2） $I_{\mathrm{s} \lambda}, I_{H \lambda}, I_{H}$ は $\tau_{05}, W$ および $\rho_{g}$ の影響を受け る. $\tau_{05}$ 扝よび $\rho_{y}$ の增加は $I_{s \lambda}$ を增加させる。この結果

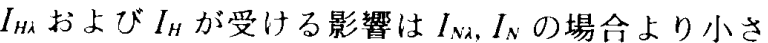
い.

（3）晴大時の $I_{H \dot{A}}$ は $h$ の時刻変化に伴って変化 し，その傾向はBirdのモデルで示されるものとよく 一致する。

（4）各月の $I_{H \lambda} お よ ひ ゙ I_{N \lambda}$ を全天甘射量および法 線面直達日射量でランク分けして整理することによ り, 雲量 6 以下の晴天時の全天日射量㧍よび法線面直 達日射量からそれらの日射スペクトルを推定すること ができる。

（5）Birdのモデルを用いて，種々の大気条件下 に扔けるhに対するI および $T$ を算出し，さらに太 陽高度の影響を修正する係数を明らかにした。

本研究を行うに当たり分光日射量の測定およがデー 夕整理に多大の助力をいただいた本学学生・藤川淳、 松井䆏，大野弘樹，川上正紀の諸君に感謝の意を表す。

本研究は文部省科学研究費一般研究 $(B)$, 課題番号 06452178 によった。 


\section{文献}

（1）馬場 弘・金山公夫, 機論, 51-467, B(1985)，2191-2201.

（2）吉时作公・筗木整一，太陽エネルギー，7-2(1981)，37-53.

（3）馬場 弘・金山公夫，機論，53-496, B(1987)，3780-3784.

（4）近藤純证・中村亘・山崎刪, 天気, 38-1 (1991), 41-48.

(5) Moon, P.. J. Franklin Inst., 230(1940), 583-617.
(6) Thekaekara, M. P., Solar Energy, 14(1973), 109-127.

(7) Leckner, B., Solar Energy, 20(1978), 143-150.

(8) Bird, R. E., Hulstrom, R. L. and Eldering, H. G., Appl. Opt., 21-8(1982), 1430-1436.

(9) Bird, R. E., Solar Energy, 32-4(1984), 461-471.

(10) Riordan, C.. Myers, D., ほか 5 名, Solar Energy, 42 1 (1989), 67-79. 